\title{
Apoptosis and Antioxidant Activities of Catharanthus rosues [L] G.Don Extract on Breast Cancer Cell Line
}

\author{
Wahyu Widowati ${ }^{*}$, Tjandrawati Mozef ${ }^{2}$, Chandra Risdian $^{2}$, Hana Ratnawati ${ }^{1}$, \\ Susy Tjahyani ${ }^{1}$, Ferry Sandra ${ }^{3}$ \\ ${ }^{1}$ Medical Research Center, Faculty of Medicine, Maranatha Christian University, Bandung \\ ${ }^{2}$ The Indonesian Institute of Sciences, Bandung \\ ${ }^{3}$ Stem Cell and Cancer Institute, Jakarta
}

\begin{abstract}
Tapak dara or Madagascar Periwinkle (Catharanthus roseus [L] G.Don), a natural plant, is empirically reported to have promising anticancer activity. To elucidate its mechanism, a research was conducted to investigate the possible ethanol extract of $C$. roseus in inducing apoptosis on breast cancer cell line (T47D). Antioxidant activity of $C$. roseus was investigated as well. Sub-GI flowcytometric apoptotic analysis result showed that extract of $C$. roseus at 6.25 $\mu \mathrm{g} / \mathrm{mL}$ induced apoptosis for $26.365 \%$. Increasing extract concentration resulted an increasing apoptotic level as well, extract at concentration of $12.5 \mu \mathrm{g} / \mathrm{mL}$ induced apoptosis for $22.235 \%$. Meanwhile doxorubicin at concentration of $10 \mu \mathrm{g} / \mathrm{mL}$ induced apoptosis for $36.055 \%$. The antioxidant activity was determined by using in vitro assay: inhibition of 2,2-diphenyl-Ipicrylhydrazyl (DPPH) scavenging activity. Antioxidant activity of $C$. roseus extract were compared to quercetin and butylated hydroxyanisol (BHA), as positive controls. The results showed that DPPH IC 50 of $C$. roseus extract, quercetin and BHA were $358.41 \mathrm{I} \mu \mathrm{g} / \mathrm{mL}, 19.200$ $\mu \mathrm{g} / \mathrm{mL}$ and $94.178 \mu \mathrm{g} / \mathrm{mL}$, respectively. We suggest that $C$. roseus extract had a potential anticancer activity by inducing apoptosis.
\end{abstract}

Keywords: antioxidant, DPPH, Catharanthus roseus, apoptosis, breast cancer, T47D

\section{INTRODUCTION}

Breast cancer is the most common cancer among women and the second leading cause of cancer deaths in women after lung cancer (Lopez and Sekharam., 2008). It is estimated that one of eight women will be diagnosed with breast cancer in women (Chen and Yan, 2007). Worldwide, one million women are estimated to be newly diagnosed with breast cancer each year (Hanf and Gonder, 2005; Abdolmohammadi et al., 2009). Cancer chemoprevention applies specific natural or synthetic chemical compounds to inhibit or reverse carcinogenesis and to suppress the development of cancer from premalignant lesions (Sarkar and Li, 2007; Abdolmohammadi et al., 2009). A major problem with present cancer chemotherapy is the serious deficiency of active drugs for the curative therapy of tumors (Valeriote et al., 2002; Kinghorn et al., 2003; Abdolmohammadi et al., 2009). The chemotherapeutic drugs including etoposide, camptothecin, vincristine, cis-platinum, cyclophosphamide, paclitaxel (Taxol), 5fluorouracil and doxorubicin have been observed to induce apoptosis in cancer cells (Kaufman et al., 2000; Johnstone et al., 2002; Abdolmohammadi et al., 2008). Among them, the agents that alter the cell cycle have been of particular interest, since cell cycle regulation is the basic mechanism underlying cell fate, i.e., proliferation, differentiation or acquire death (Dobashi et al., 2003; Abdolmohammadi et al., 2008).

*Corresponding author e-mail: wahyu_w60@yahoo.com 
Apoptosis, a type of programmed cell death, is an active process. It is a normal component of the development and health of multicellular organisms. The study of apoptosis is an important field of biological inquiry since a deficiency or an excess of apoptosis is one of the causes for cancers, autoimmune disorders, and many other diseases. Accordingly, a quick and easy assay for quantification of apoptosis would be very useful for many biological researchers (Ribble et al., 2005). Apoptosis was distinguished from necrosis, which was associated with acute injury to cells. Apoptosis is characterized by nuclear chromatin condensation, cytoplasmic shrinking, dilated endoplasmic reticulum, and membrane blebbing. Mitochondria remain unchanged morphologically (Somani et al., 2010). Apoptosis is an essential process in both multi-cellular development, and in maintaining cellular homeostasis. Moreover, failure of damaged cells to undergo apoptosis contributes to the progression of cancer as it allows the persistence of DNA damaged cells. Therefore, it is interesting to understand apoptotic signalling pathways in different cancer types. Apoptosis is morphologically defined by cell shrinkage, membrane blebbing, chromatin condensation and formation of apoptotic bodies (Mooney et al., 2002). Inducing an apoptotic response is the goal of most current chemotherapeutic interventions against cancer. The main action of anticancer agents is by triggering the apoptotic pathway. However, intrinsic alterations in the apoptotic pathway are a hallmark of cancer cells and are considered to be a major cause of drug efficacy (Lowe and Lin, 2002; Waxman and Schwartz, 2003; Shkreta et al., 2008). Clinically, apoptosis has been found to be an important mechanism in the action of radiation and many chemotherapeutic drugs (Kaufmann, 1989; Telford et al., 1994). Defects in apoptotic signalling are believed to be an important factor in successfull cancer development (Schwartzman and Cidlowski, 1992; Telford et al., 1994).

Lipid peroxidation is a free radical mediated phenomenon in biological tissues where poly unsaturated fatty acids are generally abundant. The Lipid peroxidation content is one of the most frequently used parameters for assessing the involvement of free radicals in cell damage. The probable reason for the elevated level of serum lipid peroxide in breast carcinoma may be due to defective antioxidant system which leads to the accumulation of lipid peroxides in cancer tissue which are released into the blood stream. In breast cancer tissue, the MDA level in stage IV was significantly higher as compared to stage I indicating increased free radical activity with increasing severity of cancer (Sinha et al., 2009). Lipid peroxidations are evidenced by the formation of thiobarbituric acid reactive substances (TBARS), lipid hydroperoxides (LOOH) and conjugated dienes (CD) as well as the status of the antioxidants superoxide dismutase (SOD), catalase (CAT), reduced glutathione (GSH), glutathione peroxidase (GPx) and glutathione-S-transferase (GST) in breast cancer tissues were enhanced compared to control (Kumaraguruparan et al., 2002). Antioxidant CAT, SOD also act as anti-carcinogens and inhibitors at initiation and promotion/transformation stage in carcinogenesis. Mutation caused by potassium superoxide in mammalian cells is blocked by SOD. Plasma DNA strand scission caused by xanthine/xanthine oxidase is prevented by SOD and catalase enzymes (Sinha et al., 2009).

One of the approaches used in drug discovery is the ethnomedical data approach, in which the selection of a plant is based on the prior information. $C$. rosues was used as a remedy in cancer related diseases. . Craceus (L.) G. Don (Apocynaceae), a perennial plant, commonly exists in tropical countries. It is more known as Madagascar periwinkle, the local name in Indonesia is Tapak dara. Aerial part of the plant contains about 90 different alkaloids. The isolation and purification of these indole alkaloids have been extensively studied (Sapi and Massiot., 1994), the most abundant ones are the monomers like catharanthine and vincloline. Two of the common anti-cancer drugs which are derived from this plant are vincristine and vinblastine. Crude extracts of $C$. roseus using 50 and $100 \%$ methanol had significant anticancer activity against different cell types in vitro at $<15 \mu \mathrm{g} / \mathrm{mL}$ ) (Ueda et al., 2002). Crude decoction (200 mg and 1 $\mathrm{g} \mathrm{herb} / \mathrm{mL}$ water) showed moderate in vitro antiangiogenesis effects (Ghosh and Gupta, 1980; Chattopadhyay et al, 1991, 1992). In this study, we have examined the antioxidant and apoptosis properties of the C. roseus extract.

\section{METHODS}

\section{Plant material}

C. roseus was collected from Bogor-west Java plantation (May 2009). The aerial part and root 
were collected, kept under dry tunnel $\left(40-45^{\circ} \mathrm{C}\right)$ and chopped finely using a blender.

\section{Preparation of extract}

One kilogram of dried and chopped mateial were extracted with distilled ethanol by maserasi extraction, filtered and evaporated using rotatory evaporator, produced ethanol extract of $C$. roseus $162.5 \mathrm{~g}(16.25 \%)$. The ethanol extract was stored at $4{ }^{\circ} \mathrm{C}$. The extract was dissolved in DMSO and subsequently diluted to appropriate working concentrations with DMEM culture medium (Tan et al., 2005).

\section{Cell culture}

The human breast cancer T47D cell line was obtained from the The Indonesian Institute of Sciences of Sciences Research Centre for Chemistry, Natural Products, Food and Pharmaceuticals Division, Bandung (Indonesia). The cells were grown and maintained in Dulbecco's Modified Eagle's Medium (DMEM) supplemented with 10\% $(\mathrm{v} / \mathrm{v})$ foetal bovine serum (FBS) supplemented with $100 \mathrm{U} / \mathrm{mL}$ of penicillin, $100 \mathrm{~g} / \mathrm{mL}$ of streptomycin at $37^{\circ} \mathrm{C}$ in a humidified atmosphere of $5 \% \quad \mathrm{CO}_{2}$ (Mooney et al., 2002; Tan et al., 2005).

\section{Apoptosis assay}

Cells were used in apoptotic studies when $80 \%$ confluence was reached in T25 flasks. Cells were harvested with trypsin-EDTA $(0.25 \%-0.038 \%)$, washed with PBS. T47D cells were seeded into 12 well plate at the density $10^{4}$ cells/well incubated for $24 \mathrm{~h}$ with various concentrations of extracts. After $24 \mathrm{~h}$ incubated, untreated and treated cell were rinsed with phosphate buffered saline (PBS), fixed with trypsin-EDTA and incubated $37^{\circ} \mathrm{C}$ for 5 minutes. Afterwards, the medium was added in ratio 3:1 (medium: trypsin-EDTA) and centrifuged at $1500 \mathrm{rpm}$ for 5 minutes. Supernatant was discarded. The pellet was added with $70 \%$ ethanol, and then incubated in $4^{0} \mathrm{C}$ for 5 minutes. The incubated cells were further centrifuged at $1500 \mathrm{rpm}$ for 5 minutes, and the supernatant was discarded. The cells were stained with Propidium iodide (PI) solution (in PBS) in the final concentration of $2 \mu \mathrm{g} / \mathrm{ml}$. The cell suspensions were placed in the dark by wrapping up the tubes with aluminium foil for 15 minutes prior to flow cytometric analysis. The apoptosis assay was analyzed by cell cycle analysis using flow cytometer. The apoptotic cells were determined by sub G1 area from cell cycle analysis and it was presented as percentage of cells.

\section{Antioxidant assay}

The DPPH assay was carried out as described by Unlu et al (2003), Han et al. (2004) and Frum and Viljoen (2006). Pipette $50 \mu \mathrm{L}$ of sample (C. roseus extract, quercetin and BHA) of various concentrations of the samples $(125 ; 62.5 ; 31.25$; $15.625 ; 7.813$ and $3.906 \mu \mathrm{g} / \mathrm{mL}$ ) entered at the microplate and then were added $200 \mu \mathrm{L}$ of 0.077 $\mathrm{mmol} / \mathrm{L}$ methanol solution of DPPH and the reaction mixture was shaken vigorously and kept in the dark for $30 \mathrm{~min}$ at room temperature. Furthermore, DPPH scavenging activity was determined by microplate reader at $517 \mathrm{~nm}$. The radical scavenging activity of each sample was expressed by the ratio the of lowering of the absorption of DPPH (\%), relative to the absorption (100\%) of DPPH solution in the absence of test sample (negative control).

$$
\text { scavenging } \%=\frac{A_{c}-A_{s}}{A_{c}} \times 100
$$

where $A_{s}$ and $A_{c}$ are absorbance at $517 \mathrm{~nm}$ of the reaction mixture with samples and without sample, respectively

\section{RESULTS}

\section{Morphology}

Treatment of cells with $C$. roseus extract at concentrations of $6.25 ; 12.5 ; 25 ; 50$ and $100 \mu \mathrm{g} / \mathrm{mL}$ respectively, caused morphological changes compared to normal cells and this showed indication of apoptosis (Figures 1B, 1C, 1D, 1E, 1F). Morphological changes observed in the treated cells included cell shrinkage, lead to membrane rupture. Higher concentrations of $C$. roseus extract cause more morphological changes, indicating that apoptosis occurred in cells. 

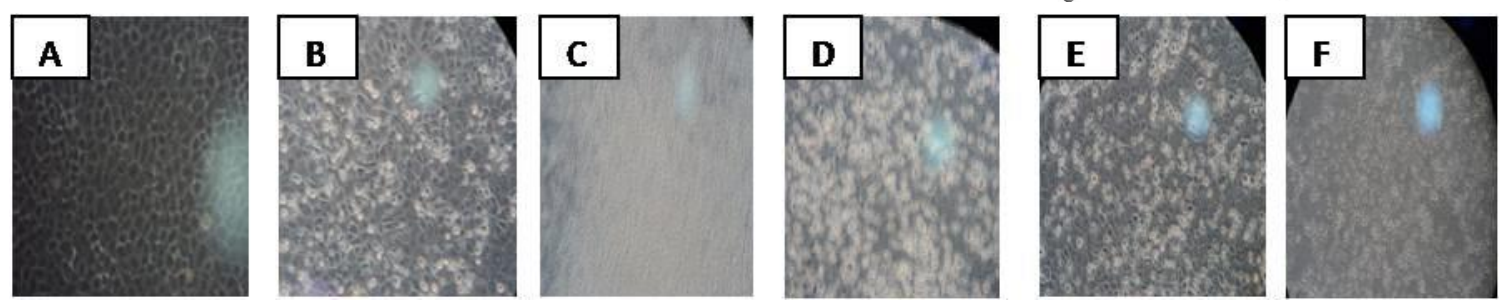

Figure I: Morphological changes T47D cells treated with $C$. roseus extract. $\left(A=\right.$ untreated T47D cells (I $\left.\times 10^{4}\right)$ ); $B=$ cells treated with $C$. roseus extract at a concentration of $6.25 \mu \mathrm{g} / \mathrm{ml}$; $C$ = cells treated $12.5 \mu \mathrm{g} / \mathrm{mL}$; $D=$ cells treated $25 \mu \mathrm{g} / \mathrm{mL} ; E=$ cells treated $50 \mu \mathrm{g} / \mathrm{mL} ; F=$ cells treated $100 \mu \mathrm{g} / \mathrm{mL}$ )

\section{Sub GI apoptosis}

The effect of $C$. roseus extract on cell cycle was analyzed by flow cytometry in duplo using concentration of $C$. roseus extract $6.25 ; 12.5 ; 25$; 50 and $100 \mu \mathrm{g} / \mathrm{mL}$, respectively. Figure 2 showed that sub G1 apoptotic content was markedly increased when cells were treated with $C$. roseus extract. The sub G1 average of untretaed was formed at $0.465 \%$ (Figure 2), whereas a concentration of $6.25 \mu \mathrm{g} / \mathrm{mL}$ resulted in $6.925 \%$ of cells being in sub G1 phase. This proportion of cells further increased at the extract concentration of $25 \mu \mathrm{g} / \mathrm{mL}$ (26.35\%), concentration $50 \mu \mathrm{g} / \mathrm{mL}(37.475 \%)$ and finally the increased concentration decreased the sub G1 apoptotic content (10.78\%).

\section{Antioxidant activity}

The DPPH free radical scavenging activity of C. roseus extract at various concentrations was measured to know the antioxidant activity. Quercetine and BHA have been used as positive controls. The $\mathrm{IC}_{50}$ (median inhibition concentration) is defined as a concentration of samples to scavenge DPPH free radical $50 \%$. The DPPH free radical scavenging activity of $C$. roseus extract, quercetin and BHA can be found in Table 1 . The $C$. roseus extract had a lowest antioxidant activity compared to quercetin and BHA.

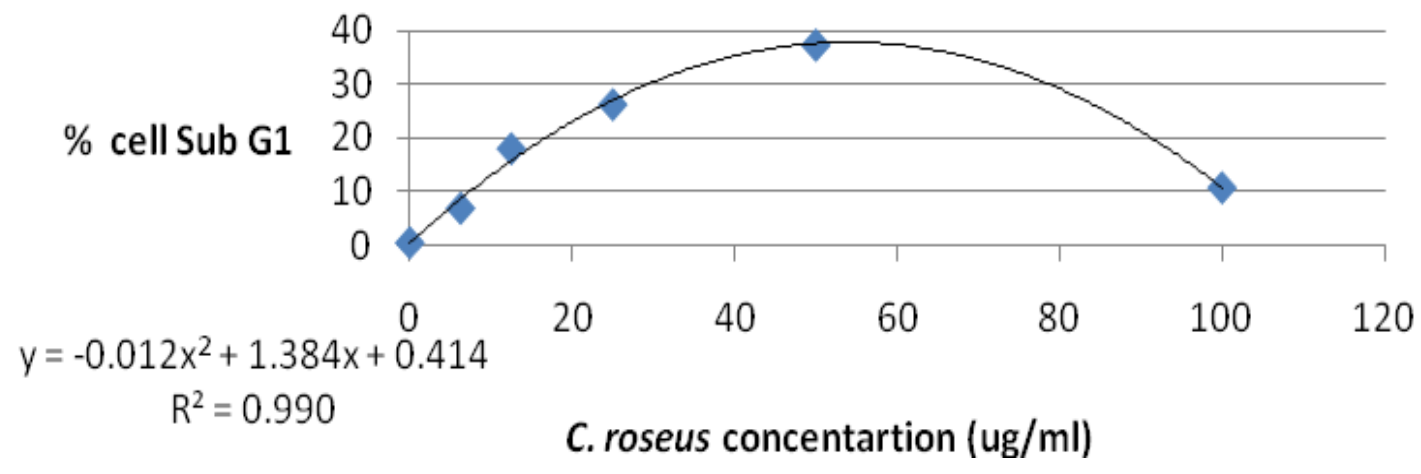

Figure 2A. Effect $C$. roseus extract on T47D cell cycle progression. 
(A)T47D Untreated
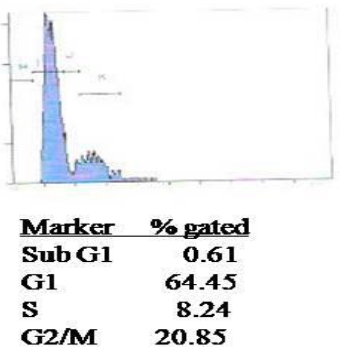

G2/M 20.85
(B)T47D C.roseus $6.25 \mu \mathrm{g} / \mathrm{mL}$
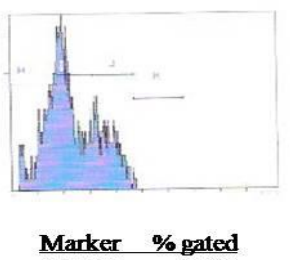

Sub G1 $\quad 31.26$

G1 40.01

S

G2/M

(E)T47D C.roseus $50 \mathrm{\mu g} / \mathrm{mL}$

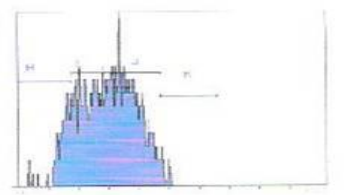

Marker \% gated

Sub G1 16.66

G1 38.4

$\begin{array}{lr}\text { S } & 39.85 \\ \text { G2/M } & 5.42\end{array}$

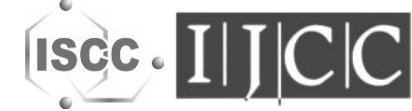

(C)T47D C.roseus $12.5 \mu \mathrm{g} / \mathrm{mL}$
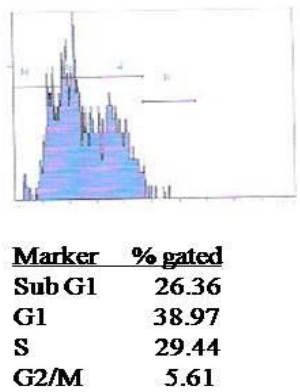

(F)T47D C.roseus $100 \mu \mathrm{g} / \mathrm{mL}$

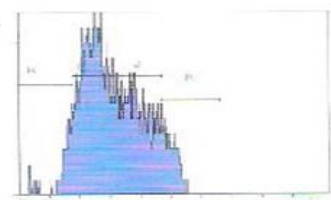

\begin{tabular}{lr} 
Marker & $\%$ gated \\
\hline Sub G1 & 10.77 \\
G1 & 42.09 \\
S & 34.57 \\
G2/M & 12.39
\end{tabular}

(G)T47D doxonubicin $10 \mu \mathrm{g} / \mathrm{mL}$

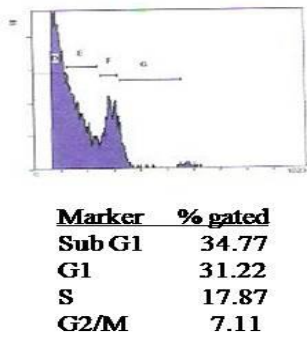

Figure 2B. Effect $C$. roseus extract on T47D cell cycle progression (A=Untreated IxI04cells; $B=C$.roseus 6.25 $\mu \mathrm{g} / \mathrm{mL}$; $C=$ C.roseus $12.5 \mu \mathrm{g} / \mathrm{mL}$; $\mathrm{D}=$ C.roseus $25 \mu \mathrm{g} / \mathrm{mL} ; \mathrm{E}=$ C.roseus 50 $\mu \mathrm{g} / \mathrm{mL}$; F= C.roseus $100 \mu \mathrm{g} / \mathrm{mL}$; $\mathbf{G}=$ doxorubicin $10 \mu \mathrm{g} / \mathrm{mL}$

Table I. Antioxidant activity of $C$. roseus extract

\begin{tabular}{lll}
\hline No & Antioxidant agents & IC $_{50}(\mu \mathrm{g} / \mathbf{m L})$ \\
\hline I & C. roseus extract & $358.4 I I$ \\
2 & Quercetin & 19.200 \\
3 & BHA & 94.178 \\
\hline
\end{tabular}

\section{DISCUSSION}

Apoptosis is characterized by fragmentation of nuclear chromatin into fragments approximately 
20 base pairs in length. Apoptosis is known to play a role in maintaining homeostasis and known to occur in mammals (McCloskey et al., 1994). The flow cytometric method has several advantages over the electrophoretic method. It analyzes a cell population one cell at a time and thereby allows discrimination of subsets within the main population. By selecting out the apoptotic subset, we can therefore quantitate the percentage of apoptotic cells in each sample.

C. roseus induced apoptosis in T47D cell line. The percentage of apoptotic cells were $6,93 \%$, $26,35 \%$ and $37,48 \%$ with concentrations of extract $6.25 \mu \mathrm{g} / \mathrm{mL}, 25 \mu \mathrm{g} / \mathrm{mL}$ and $50 \mu \mathrm{g} / \mathrm{mL}$, respectively. The more information can be found in Fig 1,2A and 2B. This result were consistent with previous studies that the $C$. roseus extract is able to induce DNA fragmentation. In each case, DNA fragmentation was characterised by oligonucleosomal size fragments of about 180-200 base pairs (bp), a well-known feature indication of programmed cell death (Compton 1992; Ahmad et al., 2010). The apototic effect of C. roseus extract were due to the presence of compounds, such as vinblastine which have anti-leukaemic properties in vitro (Caron and Herwood 2007). Vinblastine is one of the first vinca alkaloids that identified to have anti-tumour activity (Nobili et al., 2009). Further analysis of the $C$. roseus extract should be performed according to the American National Cancer Institute criterion that the $\mathrm{IC}_{50}$ limit to consider a crude extract promising for further purification be lower than $30 \mu \mathrm{g} / \mathrm{ml}$ (Suffness and Pezzuto 1990; Ahmad et al., 2010). C. roseus crude aqueous extract at very low doses inhibited the proliferation of Jurkat cells. The DNA fragmentation result showed that the cytotoxicity effect of the extract was due to programmed cell death. The extract contained compounds that specifically induce cell death in Jurkat cells (Okonogi et al. 2007; Nobili et al. 2009; Ahmad et al., 2010). Two vinca alkaloids from $C$. roseus, vinblastine, and vincristine are widely used in cancer therapy (Comin-Anduix, 2001). Both drugs inhibit the self-assembly of tubulin into microtubules at substoichiometric concentrations by forming a tubulin-drug complex at the end of a growing microtubule and thus blocking self-assembly (Margolis et al., 1980; Comin-Anduix, 2001). In addition, it is known that vinblastine induces G2/M arrest and subsequent apoptosis in different cell lines (Fan et al., 2001; Comin-Anduix, 2001).

Sample which contain antioxidant compounds will react with DPPH free radical to produce color change from purple to yellow (Kikugawa et al.,

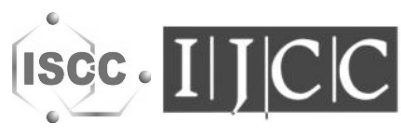

1999; Gordon, 2001). The changes in colour that was proportional to the concentration of sample were further measured at $517 \mathrm{~nm}$ (Miliauskas et al., 2003). The antioxidant assay showed that sample had lowest antioxidant activity compared to BHA and quercetine with the IC50 values are 358; 94 and 19 $\mu \mathrm{g} / \mathrm{mL}$, respectively. However, C. roseus extract induced apoptosis. This result was consistent with previous research. ROS intermediates for apoptosis signaling was demonstrated by the following four observations: (1) Antioxidants could inhibit a certain apoptosis; (2) generation of hydrogen peroxide (ROS) was detected in the cells undergoing apoptosis; (3) extracellular addition of ROS can induce apoptosis and (4) downregulation of intracellular anti-oxidant level can induce apoptosis. The involvement of ROS in apoptosis is also supported by the observation that manganese superoxide dismutase (MnSOD), which inactivates mitochondrial superoxide anion that has leaked from the electron transport (Higuchi et al., 1998). ROS Hydrogen peroxide $\left(\mathrm{H}_{2} \mathrm{O}_{2}\right)$ is able to induce apoptosis (Ray et al., 2000).

Hence, in our current results, we conclude that C. roseues extract had potential anticancer property through ROS and apoptosis induction. Investigation to know the apoptotic mechanism induced by $C$. roseus extract should be pursued.

\section{CONCLUSIONS}

C. roseus [L] G.Don extract induced apoptosis in T47D cell line, but had no antioxidant property.

\section{ACKNOWLEDGEMENT}

We are grateful to Directorate General for Higher Education, Ministry of National Education of Republic Indonesia, for Research Grant of Hibah Bersaing $(2009,2010)$ for financial support.

\section{REFERENCES}

Abdolmohammadi, M.H., Fouladdel, S., Shafiee, A., Amin, G., Ghaffari, S.M. and Azizi, E., 2008, Anticancer effects and cell cycle analysis on human breast cancer T47D cells treated with extracts of Astrodaucus persicus (Boiss.) 
Drude in comparison to doxorubicin, DARU, 16(2), II 2 - II 8.

Abdolmohammadi, M.H., Fouladdel, S., Shafiee, A., Amin, G., Ghaffari, S.M. and Azizi, E., 2009, Antiproliferative and apoptotic effect of Astrodaucus orientalis (L.) drude on T47D human breast cancer cell line: Potential mechanisms of action, African Journal of Biotechnology, 8(I7), 4265-4276.

Ahmad, N.H., Rahim, R.A. and Mat, I., 2010, Catharanthus roseus aqueous extract is cytotoxic to Jurkat leukaemic T-cells but induces the proliferation of normal peripheral blood mononuclear cells, Tropical Life Sciences Research, 2 I (2), I05-III.

Caron, J.M. and Herwood, M., 2007, Vinblastine, a chemotherapeutic drug, inhibits palmitoylation of tubulin in human leukemic lymphocytes, Chemotherapy, 53(I), 5I-58.

Chattopadhyay, R.R., Sarkar, S.K., Ganguly, S., Banerjee, R.N. and Basu, T.K., I99I, Hypoglycemic and antihyperglycemic effects of leaves of Vincarosea Linn., Ind. J. Physiol. Pharmacol, 33, I45-I5 I.

Chattopadhyay, R.R., Banerjee, R.N., Sarkar, Ganguly, S. and Basu, T.K., 1992, Antiinflammatory and acute toxicity studies with leaves of Vinca rosea Linn in experimental animals, Indian J. Physiol. Pharm.acoll, 36, 29I292.

Chen, S, and Yan, E., 2007, Breast Cancer in a Postmenopausal Obese Female Patient, Obesity Management, 3(3), I33-I 35.

Comin-Anduix, B., Agell, N., Bachs, O., Ovadi, J. and Cascante, M., 200I, A New Bis-Indole, KARs, Induces Selective $M$ Arrest with Specific Spindle Aberration in Neuroblastoma Cell Line SH-SY5Y, Moleuclar Pharmacology, 60(6), I235-I 242.

Compton, M.M., 1992, A biochemical hallmark of apoptosis: Internucleosomal degradation of the genome. Cancer Metastasis Reviews, II, 105-II9.

Dobashi, Y.T., Takehana, T. and Ooi, A., 2003, Perspectives on cancer therapy: cell cycle blockers and perturbators, Curr Med Chem., I O(23), 2549-2558.

Fan, M., Goodwin, M.E., Birrer, M.J. and Chambers, T.C., 200I, The c-Jun NH2-terminal protein kinase/AP-I pathway is required for efficient apoptosis induced by vinblastine, Cancer Res., 6I, 4450-4458.

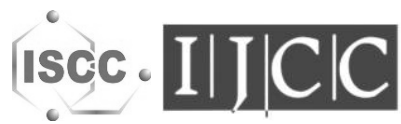

Frum, Y. and Viljoen, A.M., 2006, In vitro 5Lipoxygenase and Anti-Oxidant Activities of South African Medicinal Plants Commonly Used Topically for Skin Disease, Skin Pharmacol Physiol, 19, 329-335.

Ghosh, R.K. and Gupta, I., 1980, Effect of Vinca rosea and Ficus racemososus on hyperglycemia in rats, Indian J. Anim. Health, 19, I45-148.

Gordon, M.H., 200I, Measuring antioxidant activity. In Pokorny J, N. Yanishlieva, M. Gordon. eds. Antioxidant in food, Woodhead Publihing Limited, Cambridge England.

Han, S.S., Lo, S.C., Choi, Y.W., Kim, J.H. and Baek, S.H., 2004, Antioxidant Activity of Crude Extract and Pure Compounds of Acer ginnala Max, Bull. Korean Chem. Soc., 25(3), 389-39I.

Hanf, V. and Gonder, U., 2005, Nutrition and primary prevention of breast cancer: foods, nutrients and breast cancer risk, Eur. J. Obstet. Gynecol. Reprod. Biol., I23, I39-I49.

Higuchi, M., Honda, T., Proske, R.J. and Yeh, E.T.H., 1998, Regulation of reactive oxygen speciesinduced apoptosis and necrosis by caspase 3like proteases, Oncogene, I7, 2753-2760.

Johnstone, R.W., Ruefli, A.A. and Lowe, S.W., 2002, Apoptosis: A Link between Cancer Genetics and Chemotherapy, Cell, I08(25), I53-I64.

Kikugawa, K., Kunugi, A. and Kurechi, T., 200I, Chemistry and implications of degradation of phenolic antioxidants. In Hudson, B. J. F, ed. Food Antioxidants. Elsevier Applied Modern Toxicology, Mc. Graw-Hill, Singapore.

Kinghorn, A.D., Farnsworth, N.R., Soejarto, D.D., Cordell, G.A., Swanson, S.M., Pezzuto, J.M., Wani, M.C., Wall, M.E., Oberlies, N.H., David, J., Keoll, D.J., Kramer, R.A., Rose, W.C., Vite, G.D., Fairchild, C.R., Peterson, R.W. and Wild, R., 2003, Novel strategies for the discovery of plant-derived anticancer agents, Pharm. Biol., 4I, 53-67.

Kaufmann, S.H., 1989, Induction of endonucleolytic DNA cleavage in human acute myelogenous leukemia cells by etoposide, campotechin and other cytotoxic anticancer drugs: a cautionary note, Cancer Res., 49, 5870.

Kaufmann, S.H. and Earnshaw, W.C., 2000, Induction of Apoptosis by Cancer Chemotherapy, Experimental Cell Research. 256(I), 42-49.

Kumaraguruparan, R., Subapriya, R., Viswanathan, P. and Nagini, S., 2002, Tissue lipid peroxidation and antioxidant status in patients with 
adenocarcinoma of the breast, Clinica Chimica Acta, 325(I-2), I65-I 70.

Lopez, D. and Sekharam, M., 2008, Purified human chorionic gonadotropin induces apoptosis in breast cancer, Mol Cancer Ther., 7(9), 28372844.

Lowe, S.W. and Lin, A.W., 2000, Apoptosis in cancer, Carcinogenesis, 2 I (3), 485-495.

Margolis, R.L., Rauch, C.T. and Wilson, L., 1980, Mechanism of colchicine-dimer addition to microtubule end: implication for the microtubule polymerization mechanism. Biochemistry, 19, 5550-5557.

McCloskey, T.W., Oyaizu, N., Coronesi, M. and Pahwa, S., 1994, Use a Flow Cytometric Assay to Quantitate Apoptosis in Human Lymphocytes, Clinical Immunology and Immunopathology, 7 I (I), I4-I8.

Miliauskas, G., Venskutonis, P.R. and van Beek, T.A., 2003, Screening of radical scavenging activity of some medicinal and aromatic plant extracts, Food Chemistry, Available online 24 October 2003.

Mooney, L.M., Al-Sakkaf, K.A., Brown, B.L. and Dobson, P.R.M., 2002, Apoptotic mechanisms in T47D and MCF-7 human breast cancer cells, British Journal of Cancer, 87, 909-917.

Nobili, S., Lippi, D., Witort, E., Donnini, M., Bausi, L. Mini, E. and Cappaccioli, S., 2009, Natural compounds for cancer treatment and prevention, Pharmacological Research, 59, 365378.

Okonogi, S., Duangrat, C., Anuchpreeda, S., Tachakittirungrod, S. and Chowwanapoonpohn, S., 2007, Comparison of antioxidant capacities and cytotoxicities of certain fruit peels, Food Chemistry, 103, 839846.

Ray, G., Batra, S., Shukla, N.K., Deo, S., Raina, V., Ashok, S. And Husain, S.A., 2000, Lipid peroxidation, free radical productionand antioxidant status in breast cancer, Breast Cancer Research and Treatment, 59, 163-170.

Ribble, D., Goldstein, N.B., Norris, D.A. and Shellman, Y.G., 2005, A simple technique for quantifying apoptosis in 96 -well plates, BMC Biotechnology, 5(I2), I-7.

Rischer, H., Oresic, M., Seppa"nen-Laakso, B., Katajamaa, M., Lammertyn, F., Ardiles-Diaz, W., Van Montagu, M.C.E., Inze, D., OksmanCaldentey, K.M. and Goossens, A., 2006, Gene-to-metabolite networks for terpenoid

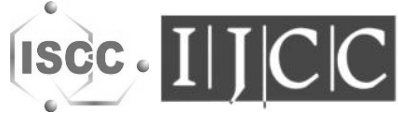

indole alkaloid biosynthesis in Catharanthus roseus cells, PNAS, I03(I4), 56I4-56I9.

Sapi, J. and Massiot, G., 1994, Heterocylclic Compounds. In: Saxton, J.E. (Ed.). Monoterpenoicls Indole Alkaloids, Part 4. Wiley, Chichester, 523-646.

Sarkar, F.H., and Li, Y.W., 2007, Targeting multiple signal pathways by chemopreventive agents for cancer prevention and therapy, Acta Pharmacol.Sin, 28, I305-1315.

Schwartzman, R.A. and Cidlowski, J.A., 1993, Apoptosis: the biochemistry and molecular biology of programmed cell death, Endo.Rev., 14, 133.

Sinha, R.J., R. Singh R, S. Mehrotra, R.K. Singh. 2009. Implications of free radicals and antioxidant levels in carcinoma of the breast: A neverending battle for survival, Indian Journal of Cancer., 46(2), I46-I50.

Shkreta, L., Froehlich, U., Paquet, E.R., Toutant, J., Elela, S.A. and Chabot, B., 2008, Anticancer drugs affect the alternative splicing of $\mathrm{Bcl}-\mathrm{x}$ and other human apoptotic genes, Mol Cancer Ther, 7(6), I398-1409.

Somani, R., Kalantri, P. and Kadam, V.J., 2010, Apoptosis: Concept, mechanism and clinical implications, Latest Reviews, 8(2).

Suffness, M., and Pezzuto, J.M., 1990, Assays related to cancer drug discovery. In: Hostettmann, K. (Ed.), Methods in plant biochemistry: Assays for Bioactivity, Academic Press, London, pp. 7I-I33.

Tan, M.L., Sulaiman, S.F., Najimuddin, N., Samian, M.R. and Muhammad, T.S.T., 2005, Methanolic extract of Pereskia bloe (Kunth) DC. (Cactaceae) induces apoptosis in breast carcinoma, T47D cell line, J. Ethnopharmacol, 96, 287-294.

Telford, W.G., King, L.E. and Fraker, P.J., 1994, Rapid quantitation of apoptosis in pure and heterogenous cell populations using flow cytometry, Journal of Immunological Methods, I 72, I-I6.

Ueda J.Y., Tezuka, Y., Banskota, A.H., Le Tran, Q. and Tran, Q.K., 2002, Antiproliferative activity of Vietnamese medicinal plants, Biol. Pharm. Bull, 25, 753-760.

Unlu, G.V., Candan, F., Sokmen, A., Dafefera, D., Polissiou, M., Sokmen, E., Donmez, and Tepe, B., 2003, Antimicrobial and antioxidant activity of the essential oil and methanol extracts of Thymus pectinatus Fisch. et Mey. 
Var. pectinatus (Lamiaceae), J. Agric. Food Chem, 5I, 63-67.

Valeriote, F., Grieshaber, C.K., Media, J., Pietraszkewics, H., Hoffmann, J., Pan, M. and McLaughlin, S., 2002, Discovery and

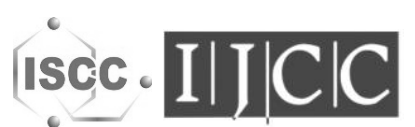

development of anticancer agents from plants, J. Exp. Ther. Oncol., 2, 228-236.

Waxman, D.J. and Schwartz, P.S., 2003, Harnessing apoptosis for improved anticancer gene therapy, Cancer Res. 63, 8563-8572. 